\title{
Study the effect of Interaction between metronidazole and Pelargonium odoratissimum aquatic extracts in vivo and in vitro on mammalian cells
}

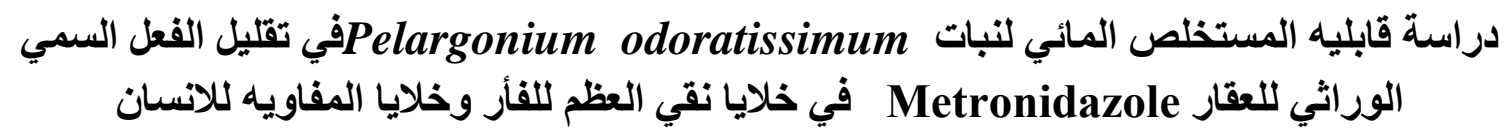

Mayassa F. AL_Romani Khulood AL_Samarrae* Esmail Shubber** Iraqi center of cancer and medical Genetic Researches / al - Mustansyria University *Biotechnology Research Center/ Al-Nahrain University $* *$ MoST, Directorate of Agric/ Res. \& Food Tech.

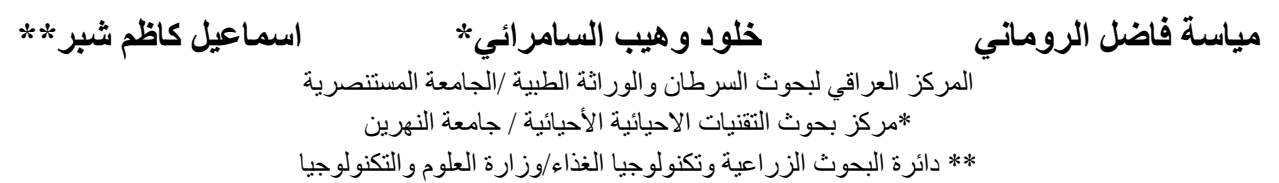

Abstract

$\widetilde{T}$ he present study was designed to investigate the role of $P$. odoratissimum aquatic extracts in reducing the genotoxic effects of metronidazole in mice in vivo and human blood lymphocyte in vitro. The parameters which evaluated in mice were used: mitotic index and chromosomal aberrations in bone marrow, while for human blood lymphocyte were mitotic index, blast index, replicative index, sister chromatid exchange and chromosomal aberrations. The cytogenetic effects of the drug and plant aquatic extracts were investigated after four days of oral administration for mice with metronidazole and aqueous extract at doses $400 \mathrm{mg} / \mathrm{kg}$ and $100 \mathrm{mg} / \mathrm{kg}$ respectively while the concentrations of metronidazole and aqueous extract in human blood lymphocyte culture was $80 \mu \mathrm{g} / \mathrm{ml}$, and $10 \mu \mathrm{g} / \mathrm{ml}$ respectively. An interaction study of plant extract with metronidazole was carried out through three types of treatments (before, after and mixture of plant extract and drug treatment) to determine the activity of $P$. odoratissimum aqueous extract in reducing the side effects of drug both in vitro and in vivo. Aquatic extract of P.odoratissimum at the concentration of $10 \mu \mathrm{g} / \mathrm{ml}$, showed a protective value against the genotoxic effect of metronidazole at $80 \mu \mathrm{g} / \mathrm{ml}$. concentration .In mouse bone marrow cells and human blood lymphocyte culture, this was more pronounced in pre-treatment and simultaneous treatment than in post-treatment. So $P$. odoratissimum aquatic extract is considered as desmutagen in the first order and bioantimutagen in the second order, as a result for its ability to repair CA and increase $\mathrm{MI}$ in mouse system and in human blood lymphocyte culture system . It also had the ability to increase BI and RI and decrease SCE in human blood lymphocytes culture in vitro.

المستخلص

يهاف البحث الى دراسه قابليه المستخلص المائي لنبات العطرة P. odoratissimum في تثبيط التأثير السمي

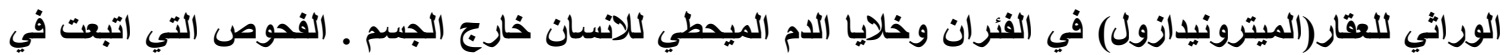

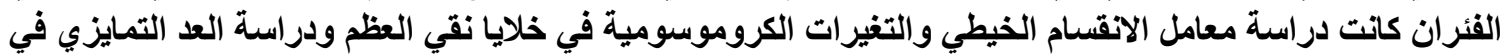


خلايا دم الفئران رأما في خلايا الام الميحطي للإنسان خارج الجسم فتضنت الاراسة الانقسام الخيطي,التغيرات

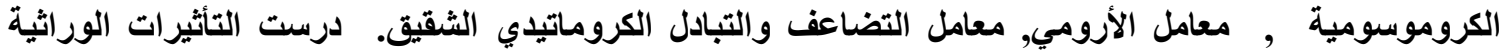

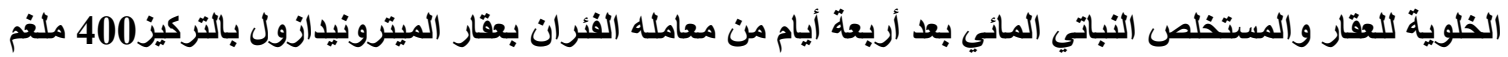

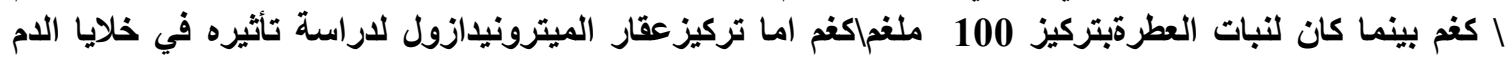

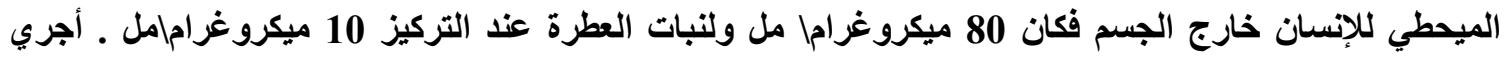

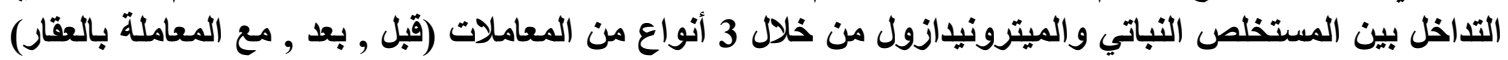

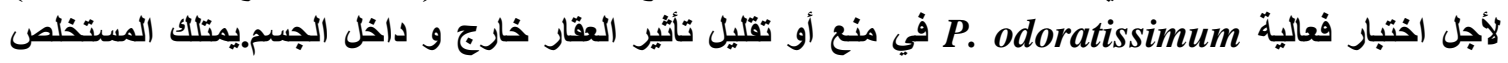

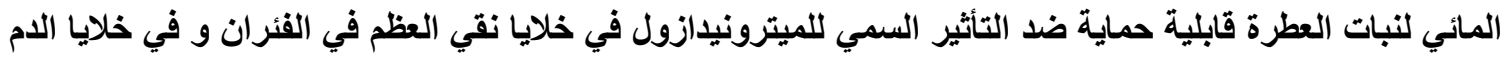

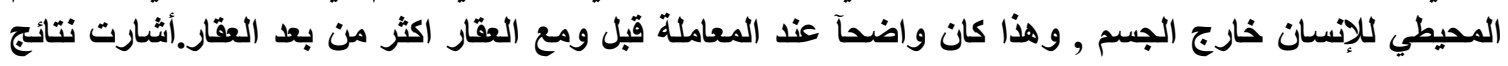

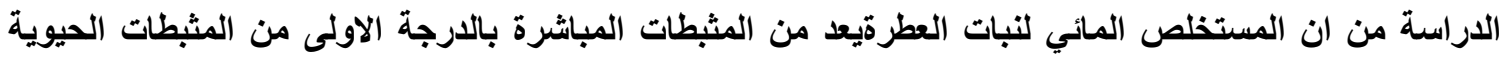

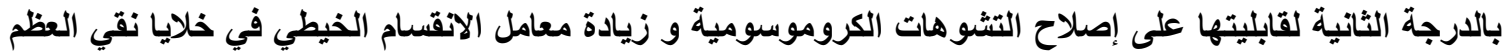

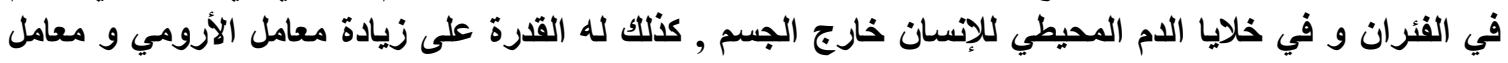

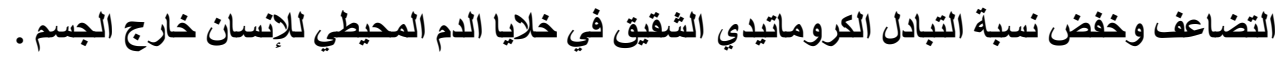

\section{Introduction}

Herbal medicines include dietary supplements that contain herbs, either singly or in mixtures which also called botanicals, herbs are plants or plant parts used for their therapeutic properties. Since herbal medicines are classified as dietary supplements, there are no Food and Drug Administration (FDA) regulations regarding accuracy of active ingredients content or efficacy and safety of active ingredients. Concurrent use of herbs may mimic, magnify, or oppose the effect of drugs [1].

Metronidazole is a synthetic antibacterial and antiprotozoal agent that belongs to the nitroimidazole class. It is an effective therapy against protozoa such as Trichomonas vaginalis, amoebiasis, and giardiasis. In addition, it is one of the most effective drugs available against anaerobic bacterial infections [2]. Metronidazole is indicated in the treatment of extra intestinal amoebiasis, as well as acute intestinal amoebiasis caused by Entamoeba histolytica [3]. Metronidazole is also indicated in the treatment of bone, joint and brain abscess infections caused by Bacteroides species, including the $B$. fragilis group (B. fragilis, B. distasonis, B. ovatus, B. thetaiotaomicron, B. vulgatus) [4]. Another important infections treated by MTZ is that of the central nervous system (CNS) infections including meningitis and in the treatment of endocarditis caused by Bacteroides species, including the $B$. fragilis group [5].

Pharmacokinetic interactions involve changes in the way of herbs and drugs to move through the body and can alter the amount, or level, of drug(s) in the body. In vivo studies with pre-clinical species are not predictive of the human clinical situation. Although in vitro kinetic data also have limitations when extrapolating in vivo, in vitro testing has become more common due to reduced cost and higher throughput [6].

Naturally occurring substances in foods have been shown to serve as dietary antimutagens. Therefore, many studies have been expanded on natural compounds which had the antimutagenic effect, which work in different mechanism to reduce the action of these mutagenic compounds, in contrast these mutagenic compounds have a mechanism to 
convert into electrophilic radicals capable to reach into target site protein, RNA and DNA and made damage [7].

The mechanisms of antimutagenesis have been classified into two major processes by [8], one desmutagens and other bioantimutagens. Antimutagens in the diet can be broadly classified into two groups, the bioantimutagens and the desmutagens, the former acting on DNA and the latter not affecting genetic material directly [9]. Desmutagens encompass all agents that affect mutagenicity through mechanisms other than DNA repair or replication. Dietary desmutagens may function as chemical inactivates, enzymatic inducers, mutagen scavenging or antioxidants; they create this effect without directly affecting the genetic material [10]. The bioantimutagens are naturally occurring substances that reduce mutant yield by acting on the DNA repair or replicative processes. These compounds act after a DNA adduct has formed but before the DNA lesion is fixed into a mutation [11]. Bioantimutagens may a) inhibit the induction of strand-on-strand DNA repair, reducing replication of mutated strands; b) in cells containing mutations, make the "proofreading" in repair more like that seen in normal cells; or c) accelerate the recombination strand-onstrand repair rate, thus reducing the number of mutated strands [12].

The aim of this work was to reduce the side effects of existing drugs. Researchers could develop matched drug-antidote pairs at the beginning of the drug development process to enable the control of drug activity in patients. This approach could be reached by testing genome stability through the following:-

1. Studying the cytogenetic effect of metronidazole and $P$. odoratissimum aquatic extract by using (mitotic index, chromosomal aberration assays) in mouse bone marrow cells in vivo and in human blood lymphocytes cultures in vitro.

2. Studying the effect of metronidazole and plant aquatic extract on the blood leukocyte both total and differential count in mice.

3. Investigating the ability of aquatic extract of P.odoratissimum in reducing the genotoxic effects produced by metronidazole.

\section{Material and Methods}

\section{-Mice}

Eight to ten week old albino Swiss mice belong to the strain of Mus musculus were received from Biotechnology Research Center Al-Nahrain University with weight of (2530)grams. They were divided into four groups, each group includes 3 mice that were used in separated plastic cage and those cages were kept in normal condition $23-25^{\circ} \mathrm{C}$ (room temperature). All those animals were fed with suitable quantity and quality of complete diet and water.

\section{-Human blood samples}

Five milliliters of peripheral blood samples were collected randomly from the students of AL-Nahrain University in hyperinized syringe.

\section{-Plant Extraction}


Fifty milligrams of powdered leaves were infused in $250 \mathrm{ml}$ of distilled water (D.W.). Then extracted in the reflex for 3 hours, filtrated and placed in the rotary evaporator until it became dry. Two grams of dried plant extract were taken and dissolved in sterile $(20 \mathrm{ml})$ PBS was used for mouse studies While for human blood culture studies, $0.5 \mathrm{gm}$ of plant extract was dissolved to make a solution $(10 \mathrm{mg} / \mathrm{ml})$, and then sterilized by filtration and kept at $4^{\circ} \mathrm{C}$ until being used .

\section{(MTZ) - Metronidazole}

Metronidazole was obtained from (Samara Drug Industry company) at concentration of $500 \mathrm{mg} /$ tablet, dissolved in sterile $2 \mathrm{ml}$ PBS to make a stock solution and from this solution a dose of $200 \mathrm{mg} / \mathrm{kg}$ was prepared [13] and to be used for mouse studies. While for human blood culture studies, one tablet of metronidazole was dissolved in $100 \mathrm{ml}$ of sterile PBS to make the concentration of $80 \mu \mathrm{g} / \mathrm{ml}$, and then sterilized by filtration and kept at $4^{\circ} \mathrm{C}$ until being used.

\section{-White blood cells count [14]}

A small drop of heparinized blood was put on the end of clean, dry slides. A pusher slide was place at an angle of $30^{\circ}$ to $45^{\circ}$ to the slide and then moved it back to make contact with the drop. The forward movement of the pusher spreads the blood on the slide. The blood film was allowed to dry in the air. The slides were completely covered with Giemsa stain, after 3 minutes the slides were washed gently and then examined under light microscope.

No. of cells $($ cells $/ \mathrm{mm} 3$ blood $)=($ total no. of leukocyte $\times$ cells $\%)$

\section{-Cytogenetic analysis:-}

Two parameters were investigated in mouse bone marrow cells ;mitotic index(MI) and chromosomal aberrations(CA).while five parameters were investigated in human blood culture:-

\section{Mitotic Index (MI) Assay}

The slides were examined under high power $(40 \mathrm{X})$ of compound light microscope and (1000) of divided and non-divided cells were counted and the mitotic index was calculated according to the following equation:

Mitotic index $=$ no. of the dividing cells/ total no. of the cells $(1000) \times 100$

\section{2. last Index (BI) Assay}

The slides were examined under high power (40X) of compound light microscope and (1000) cells were counted to calculate the percentage rate of the blast cells according to the following equation:

Blast index $(\mathrm{BI})=$ no. of the blast cells/total no. of cells $(1000) \times 100$

\section{Chromosomal Aberrations (CAs) Assay}

The prepared slides were examined under the oil immersion lens for 100 divided cells per each animal or blood lymphocytes culture, and the cells should be at the first metaphase stage of the mitotic division where the chromosomal aberrations are clear and the percentage of these aberrations was estimated.

\section{Sister Chromatid Exchange (SCE) Assay}


Sister chromatid exchange was counted in 50 well spread second metaphases by using hochest staining technique.

\section{Replicative index (RI) assay}

The replicative index (RI) was determined by counting the number of cells at the first, second and the third metaphase in (100) a cell at metaphase, the RI was calculated according to the following equation:

$\mathrm{RI}=(1 \mathrm{xM} 1 \%)+(2 \mathrm{xM} \%)+(3 \mathrm{xM} \% \%) / 100$

-The Protective Value of $P$. odoratissimum Aqueous Extract:

The protective value of Pelargonium odoratissimum aqueous extract was calculated according to the following equation:-

Protective value $=\mathrm{A}-\mathrm{C} / \mathrm{A}-\mathrm{B} \times 100$

$\mathrm{A}=(+)$ ve control (treatment with MTZ only)

$\mathrm{B}=(-)$ ve control (treatment with PBS only)

$\mathrm{C}=$ interaction group (treated with MTZ and plant aqueous extract). (15)

\section{Statistical Analysis}

One or two way analysis of variance was performed to test whether group variance was significant or not, the comparison between groups were made using SAS package [16].

\section{Result and Discussion}

Interaction of plant Aqueous Extract with Metronidazole on Mouse Bone Marrow cells:

This experiment was designed to study the interaction of plant extract with the mutagenic effect of MTZ and its results showed a high percentage of CAs and decrease percentage at MI in the bone marrow of mice Table(1).

Table (1): Interaction between MTZ and P. odoratissimum Aqueous Extract in Mouse Bone Marrow Cells in vivo.

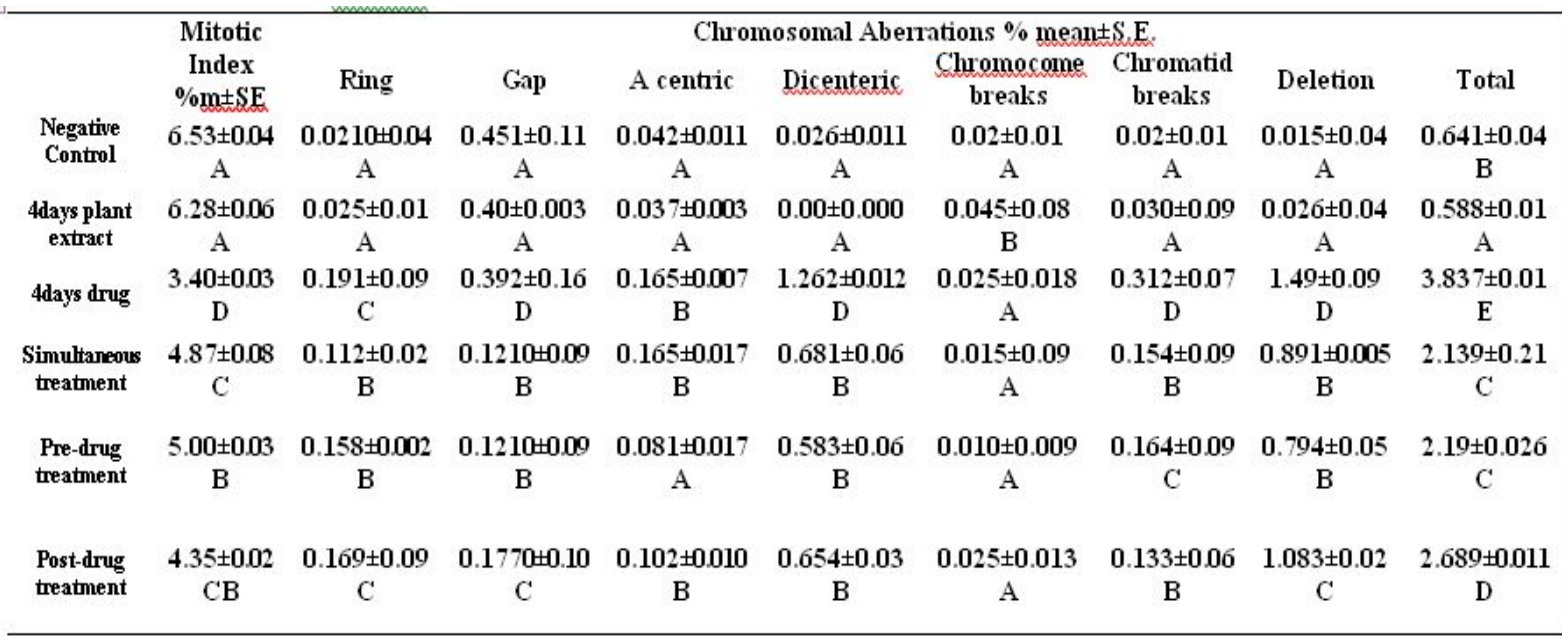

Differences A, B, C, D, E are significant $(P<0.05)$ to compression rows.

\section{- Pre-Drug Treatment with Plant Aqueous Extract:}

The results of this experiment were represented in figure (1), which showed the ability of plant extract to reduce the effect of MTZ on MI and CA in the mouse bone marrow. This 
results may be attributed to the active compounds in the plant extracts such as flavonoids and other chemical constituents in the crude plant extract [17].

The crude extract contains a combination of different active constituents in which they might act together to reduce the genotoxic effect of MTZ. Of these compounds, were the flavoniods, saponins, gerauillol and citronillol. These active compounds may play an important role in reducing the genotoxicity of the drug, for example flavonoids were strong antioxidants that prevent DNA damage at low concentrations and have the ability to scavenging the hydroxyl radicals, superoxide an ions, and lipid peroxy radicals, e.g.Green tea, onions, apples, grapes, ginkgo, and silybum were just a few of the many thousands of plants that contain flavonoid antioxidants[18], whereas saponins are compounds derived from plant sources and exhibit powerful antioxidant properties and the method of action of saponin appears to be by DNA repairing cytosolic proteins and the ability to decrease oxidative stress by up-regulating the powerful antioxidant glutathione. These chemical constituents of plant aqueous extract may also linked to the drug or its metabolites to form non-absorbable complexes or act to prevent activation of the drug by inhibiting cytochrom P 450 enzymes, while other suggested that there ingredients may inhibit the metabolic activation of the drug [19].
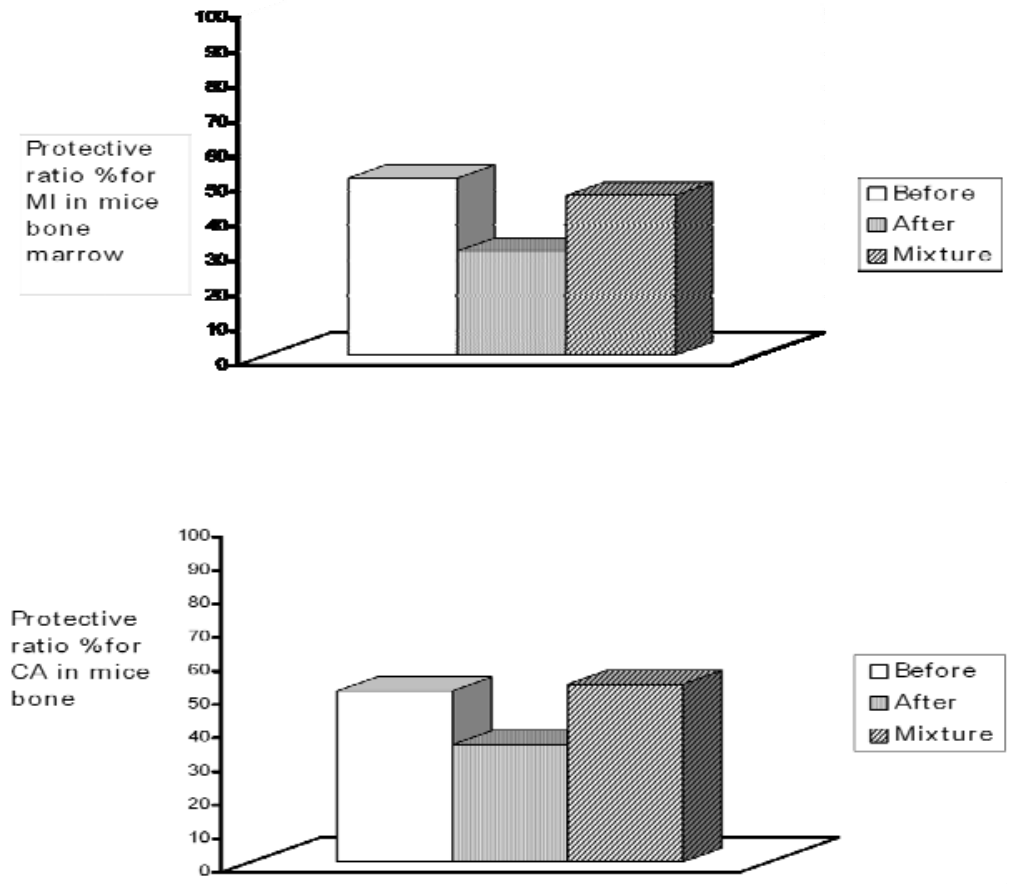

Fig (1): The protection ratios for MI (A) and CA (B) provided by $P$. odoratissimum when given before, after and as a mixture in vivo. 


\begin{abstract}
- Post-Drug Treatment with Plant Aqueous Extract
From these results it was found that the plant extract have the ability to reduce the effect of the drug Figure (1).

$P$. odoratissimum aqueous extract could be considered as bioantimutagen for its ability to decrease the effect of MTZ in post-treatment. It was clear that post drug treatment with plant extract may activate the suppressing agent or activate the promoters of DNA repair mechanism, or may increase the error free repair fidelity in the cell [20].
\end{abstract}

\title{
- Simultaneous Treatment with Mixture of Plant Aqueous Extract and MTZ
}

Results showed that using the plant extract at the same time with drug can reduce the genotoxic effect.

The ability to reduce CAs was similar to the reduction ability of pre-treatment Figure (1), which means that they have similar mechanism to reduce genotoxicity of MTZ. Many plant extracts were considered as desmutagen. It is possible to consider $P$. odoratissimum aqueous extract as a desmutagens for its ability to decrease the effect of MTZ by chemical inactivates, enzymatic inducers, mutagen scavenger or as antioxidants in simultaneous treatment.

Flavonoids of $P$. odoratissimumaqueous extract have the ability to increase the detoxifying enzymes in the body and therefore reduce the effect of these mutagenic materials and their metabolites [17].

Treatment with plant extract before the drug and as a mixture provided protection ratios for MI and CAs more than these ratios when given after drug. So, P. odoratissimum could be classified as desmutagen in the first order, and bioantimutagen in the second order.

\section{Interaction between Plant Aqueous Extract and MTZ on Human Blood Lymphocytes Culture}

The concentrations of both drug and plant extract used in this experiment were selected according to the harmful concentration of drug and more useful plant extract concentration to human blood lymphocyte Table $(2,3)$.

\section{-Pre and post-Drug Treatment}

The pre-treatment showed that plant aqueous extract has the ability to reduce the effect of the drug, when culturing human blood lymphocyte for $48 \mathrm{hr}$. with a plant aqueous extract at concentration $10 \mu \mathrm{g} / \mathrm{ml}$ and then separated the plant aqueous extract and added a media with drug at concentration of $80 \mu \mathrm{g} / \mathrm{ml}$, this pre-treatment significantly reduced $(\mathrm{p}<0.05)$ the effect of the drug as shown in figure $(2,3)$ while, post-drug treatment show different protection effect as shown in figure $(2,3)$. Furthermore, treatment with a Mixture of $P$. odoratissimum Extract and MTZ illustrate that the mixture had the ability to decrease the mutagenic activity of MTZ figure (2).

This might be related to the active constituent like saponins and flavonoids in the plant which can modulate the mutagenic effects of MTZ [19].

The Effect of plant drug interaction in Mice Leukocytes count

This interaction on leukocyte of mouse of the three types of treatment, pre, post and simultaneous treatmentas shown in Table (3). The damage effect of both MTZ and $P$. odoratissimum extracts expected to effect on the quantity of WBC to decrease in range between 7 to 20 days following oral administration [21], but in our experiment administrated for five days so no effect was observe as shown in Table(4). 
Table (2): Interaction between P. odoratissimum Aqueous Extract and MTZ in Human Blood Lymphocyte Culture (in vitro)

\begin{tabular}{|c|c|c|c|c|c|c|c|}
\hline \multirow{2}{*}{$\begin{array}{l}\text { Type of } \\
\text { treatment }\end{array}$} & \multirow{2}{*}{$\begin{array}{c}\text { Blasto } \\
\text { Index } \\
\text { \%mean } \pm \text { S.E. }\end{array}$} & \multirow{2}{*}{$\begin{array}{c}\text { Mitotic } \\
\text { Index } \\
\% \text { mean } \pm \text { S.E. }\end{array}$} & \multicolumn{3}{|c|}{$\begin{array}{c}\text { Cell cycle } \\
\text { progression \% } \\
\text { (mean) }\end{array}$} & \multirow{2}{*}{$\begin{array}{c}\text { Replective } \\
\text { Index } \\
\text { \%meantS.E. }\end{array}$} & \multirow{2}{*}{$\begin{array}{c}\text { Sister } \\
\text { chromatid } \\
\text { exchange } \\
\% \text { mean } \pm \text { S.E }\end{array}$} \\
\hline & & & M1 & M2 & M3 & & \\
\hline $\begin{array}{l}\text { Negative } \\
\text { Control }\end{array}$ & $\begin{array}{c}37.30 \pm 0.04 \\
\text { GF }\end{array}$ & $\begin{array}{c}3.82 \pm 0.012 \\
\mathrm{E}\end{array}$ & 34 & 31 & 35 & $\begin{array}{c}2.01 \pm 0.01 \\
\mathrm{E}\end{array}$ & $\begin{array}{c}6.40 \pm 0.02 \\
\mathrm{~A}\end{array}$ \\
\hline $\begin{array}{c}\text { Plant } \\
\text { extract }(72 \\
\text { hr.) } \\
10 \mu \mathrm{g} / \mathrm{ml}\end{array}$ & $\begin{array}{c}38.75 \pm 0.05 \\
G\end{array}$ & $\begin{array}{c}3.82 \pm 0.012 \\
\mathrm{E}\end{array}$ & 34 & 33 & 33 & $\begin{array}{c}1.99 \pm 0.02 \\
E\end{array}$ & $\begin{array}{c}6.33 \pm 0.12 \\
\mathrm{~A}\end{array}$ \\
\hline $\begin{array}{c}\text { Drugg(72 hr.) } \\
80 \mu \mathrm{g} / \mathrm{ml}\end{array}$ & $\begin{array}{c}10.75 \pm 0.15 \\
\mathrm{~A}\end{array}$ & $\begin{array}{c}0.67 \pm 0.02 \\
\mathrm{~A}\end{array}$ & 79 & 20 & 1 & $\begin{array}{c}1.20 \pm 0.02 \\
\mathrm{~A}\end{array}$ & $\begin{array}{c}30.32 \pm 0.03 \\
\mathrm{D}\end{array}$ \\
\hline $\begin{array}{c}\text { Simultaneous } \\
\text { treatment }\end{array}$ & $\begin{array}{c}31.62 \pm 0.87 \\
\mathrm{EF}\end{array}$ & $\begin{array}{c}2.75 \pm 0.013 \\
\mathrm{CD}\end{array}$ & 36 & 36 & 28 & $\begin{array}{c}1.92 \pm 0.01 \\
E\end{array}$ & $\begin{array}{c}16.00 \pm 0.5 \\
C\end{array}$ \\
\hline $\begin{array}{c}\text { Plant extract } \\
\text { for } \\
(48 \mathrm{hr} .)\end{array}$ & $\begin{array}{c}35.30 \pm 0.07 \\
\mathrm{DE}\end{array}$ & $\begin{array}{c}3.85 \pm 0.010 \\
D\end{array}$ & 36 & 31 & 33 & $\begin{array}{c}1.97 \pm 0.05 \\
\mathrm{E}\end{array}$ & $\begin{array}{c}5.87 \pm 0.5 \\
\mathrm{~A}\end{array}$ \\
\hline $\begin{array}{c}\text { Drug for (48 } \\
\text { hr.) }\end{array}$ & $\begin{array}{c}17.35 \pm 0.50 \\
B\end{array}$ & $\begin{array}{c}0.95 \pm 0.01 \\
\mathrm{~A}\end{array}$ & 63 & 22 & 15 & $\begin{array}{c}1.52 \pm 0.01 \\
B\end{array}$ & $\begin{array}{c}30.60 \pm 0.03 \\
\mathrm{D}\end{array}$ \\
\hline $\begin{array}{l}\text { Pre-drug } \\
\text { treatment }\end{array}$ & $\begin{array}{c}33.75 \pm 0.30 \\
\mathrm{D}\end{array}$ & $\begin{array}{c}2.5 \pm 0.18 \\
\text { B }\end{array}$ & 41 & 38 & 21 & $\begin{array}{c}1.80 \pm 0.07 \\
D\end{array}$ & $\begin{array}{c}15.12 \pm 0.007 \\
\mathrm{C}\end{array}$ \\
\hline $\begin{array}{l}\text { Post-drug } \\
\text { treatment }\end{array}$ & $\begin{array}{c}23.95 \pm 0.70 \\
C\end{array}$ & $\begin{array}{c}2.27 \pm 0.02 \\
B\end{array}$ & 48 & 31 & 21 & $\begin{array}{c}1.73 \pm 0.04 \\
\mathrm{C}\end{array}$ & $\begin{array}{c}14.39 \pm \text { ' } 02 \\
\text { B }\end{array}$ \\
\hline
\end{tabular}

Differences A, B, C, D, E are significant $(\mathrm{P}<0.05)$ to compression rows.

Table (3): The Effect of Interaction between P. odoratissimum Aqueous Extract and MTZ on Chromosomal Aberrations of Human Blood Lymphocyte Culture.

\begin{tabular}{|c|c|c|c|c|c|c|c|}
\hline \multirow[b]{2}{*}{ Type of Treatment } & \multicolumn{7}{|c|}{ Chromosomal Aberration \% \%mean \pm S.E } \\
\hline & A centric & Dicenteric & $\begin{array}{c}\text { Chromosome } \\
\text { breaks }\end{array}$ & $\begin{array}{c}\text { Chromatid } \\
\text { breaks }\end{array}$ & Deletion & Gap & Total \\
\hline & 0.00 & 0.00 & 0.00 & $0.050 \pm 0.01$ & 0.00 & $0.210 \pm 0.01$ & $0.260 \pm 0.02$ \\
\hline Negative Control & A & A & A & A & A & A & A \\
\hline Plant extract & 0.00 & 0.00 & 0.00 & $0.015 \pm 0.5$ & 0.00 & $0.245 \pm 0.01$ & $0.260 \pm 0.03$ \\
\hline $10 \mu \mathrm{gr} / \mathrm{ml}$ & A & A & $\mathbf{A}$ & A & A & A & A \\
\hline $\begin{array}{c}\text { Drug } \\
(72 \mathrm{hr} .) \\
80 \mu \mathrm{g} / \mathrm{ml}\end{array}$ & $\begin{array}{c}0.420 \pm 0.04 \\
B\end{array}$ & $\begin{array}{c}0.350 \pm 0.02 \\
C\end{array}$ & $\begin{array}{c}0.412 \pm 0.09 \\
D\end{array}$ & $\begin{array}{c}0.463 \pm 0.0010 \\
C\end{array}$ & $\begin{array}{c}0.400 \pm 0.013 \\
C\end{array}$ & $\begin{array}{c}1.573 \pm 0.012 \\
D\end{array}$ & $\begin{array}{c}3.618 \pm 0.026 \\
E\end{array}$ \\
\hline $\begin{array}{l}\text { Simultaneous } \\
\text { treatment }\end{array}$ & $\begin{array}{c}0.12 \pm 0.09 \\
\text { B }\end{array}$ & $\begin{array}{c}0.137 \pm 0.07 \\
\text { B }\end{array}$ & $\begin{array}{c}0.021 \pm 0.09 \\
\text { B }\end{array}$ & $\begin{array}{c}0.023 \pm 0.05 \\
A\end{array}$ & $\begin{array}{c}0.10 \pm 0.01 \\
B\end{array}$ & $\begin{array}{c}1.314 \pm 0.03 \\
\mathrm{C}\end{array}$ & $\begin{array}{c}1.835 \pm 0.09 \\
\text { B }\end{array}$ \\
\hline $\begin{array}{l}\text { Plant extract for } \\
\text { (48 hr.) }\end{array}$ & $\begin{array}{c}0.00 \\
\mathrm{~A}\end{array}$ & $\begin{array}{c}0.00 \\
\mathrm{~A}\end{array}$ & $\begin{array}{c}0.047 \pm 0.01 \\
\text { B }\end{array}$ & $\begin{array}{c}0.010 \pm 0.01 \\
A\end{array}$ & $\begin{array}{c}0.00 \\
\mathrm{~A}\end{array}$ & $\begin{array}{c}0.22 \pm 0.02 \\
\mathrm{~A}\end{array}$ & $\begin{array}{c}0.277 \pm 0.05 \\
\mathrm{~A}\end{array}$ \\
\hline Drug for(48 hr.) & $\begin{array}{c}0.390 \pm 0.005 \\
\text { B }\end{array}$ & $\begin{array}{c}0.340 \pm 0.02 \\
C\end{array}$ & $\begin{array}{c}0.370 \pm 0.09 \\
D\end{array}$ & $\underset{C}{0.411 \pm 0.10}$ & $\begin{array}{c}0.400 \pm 0.012 \\
C\end{array}$ & $\begin{array}{c}1.370 \pm 0.026 \\
C\end{array}$ & $\begin{array}{c}3.281 \pm 0.15 \\
\mathrm{D}\end{array}$ \\
\hline $\begin{array}{l}\text { Pre-drug } \\
\text { treatment } \\
\text { Post-drug } \\
\text { treatment }\end{array}$ & $\begin{array}{c}0.50 \pm 0.002 \\
\mathrm{C} \\
0.285 \pm 0.010 \\
\mathrm{AB}\end{array}$ & $\begin{array}{c}0.00 \\
A \\
0.230 \pm 0.08 \\
C \\
\end{array}$ & $\begin{array}{c}0.130 \pm 0.02 \\
C \\
0.217 \pm 0.01 \\
D \\
\end{array}$ & $\begin{array}{c}0.230 \pm 0.06 \\
\text { B } \\
0.293 \pm 0.05 \\
\text { B } \\
\end{array}$ & $\begin{array}{c}0.110 \pm 0.05 \\
B \\
0.05 \pm 0.01 \\
B \\
\end{array}$ & $\begin{array}{c}0.300 \pm 0.01 \\
B \\
1.387 \pm 0.06 \\
C \\
\end{array}$ & $\begin{array}{c}1.27 \pm 0.09 \\
\text { B } \\
2.462 \pm 0.09 \\
\text { CD } \\
\end{array}$ \\
\hline
\end{tabular}

Differences A, B, C, D, E are significant $(P<0.05)$ to compression rows 

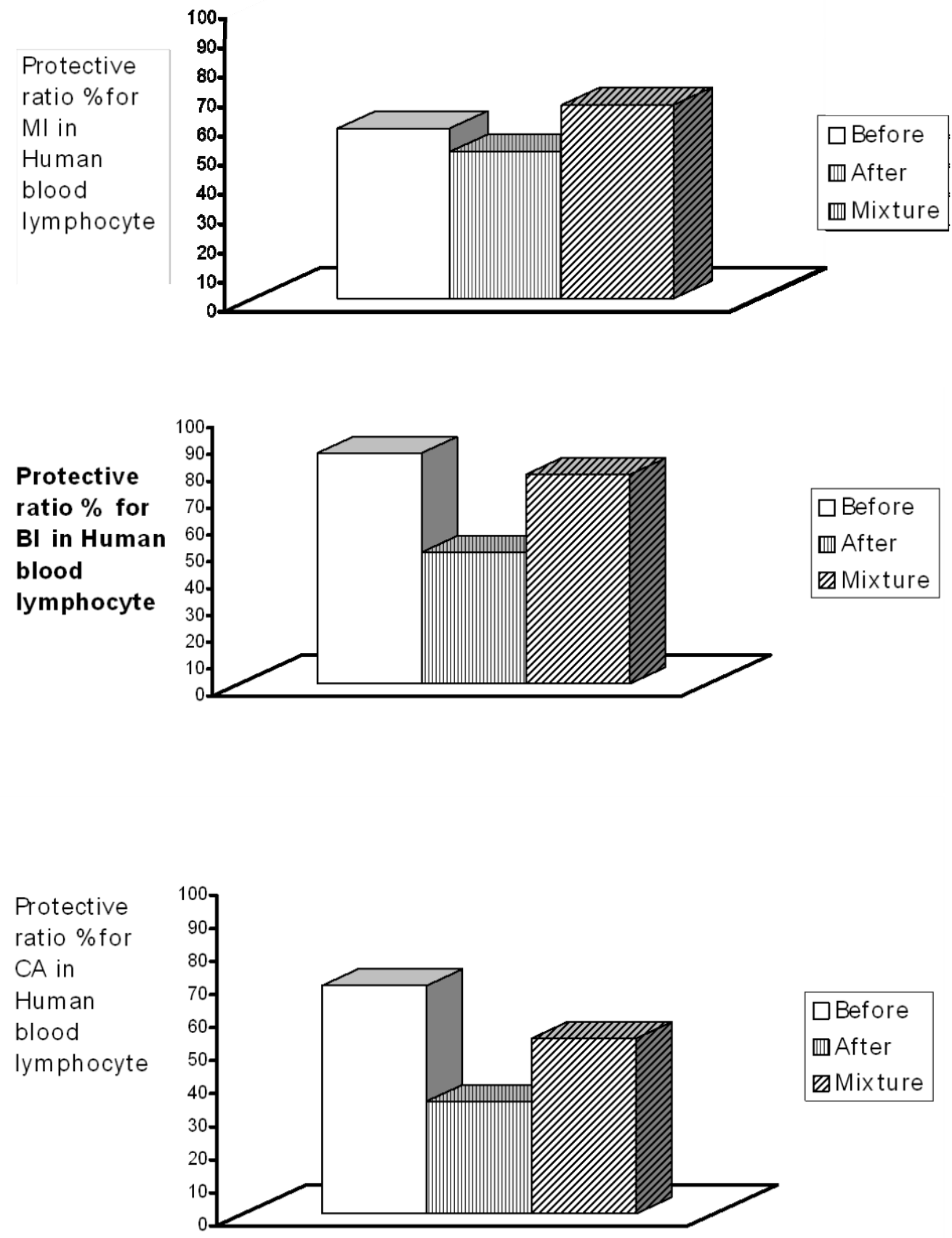

Fig (2): The protection ratios for MI, BI and CAs that provided by $P$. odoratissimum when given before, after and as a mixture (in vitro). 

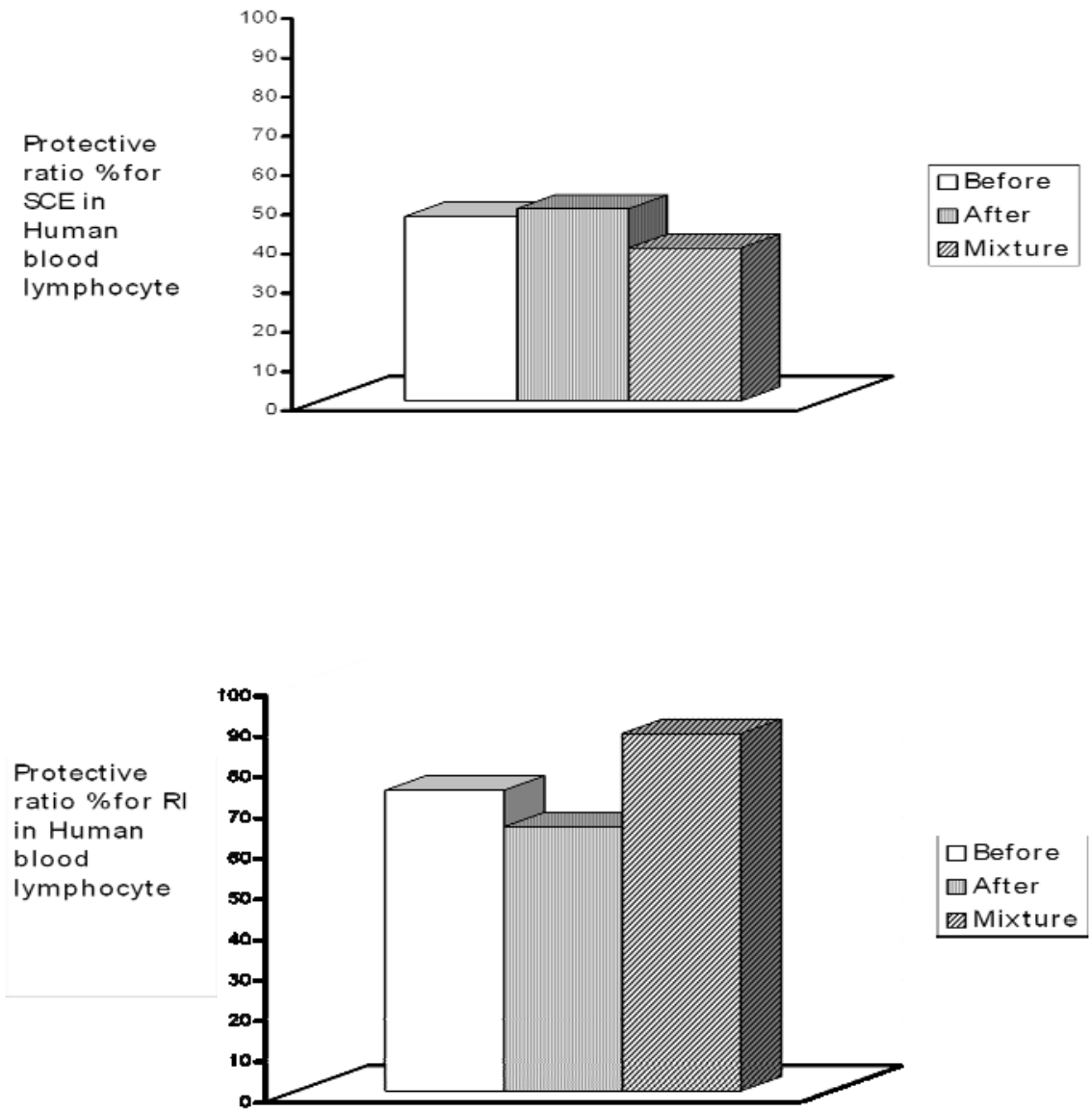

Fig (3): The protection ratios for RI and SCE that provided by $P$. odoratissimum when given before, after and as a mixture in vitro.

Table (4): Interaction between Drug and Plant Aqueous Extract and their Effect on Differential and Total Count of Blood Leukocyte.

\begin{tabular}{|c|c|c|c|c|c|c|}
\hline \multirow{2}{*}{$\begin{array}{l}\text { Doses of } \\
\text { treatment }\end{array}$} & \multicolumn{6}{|c|}{ mean \pm S. E. (cell/cu. mm. bloods) } \\
\hline & Total & lymphocyte & Neutrophil & Monocyte & Basophil & Eosnophil \\
\hline Control & $8780 \pm 0.2 \mathrm{~A}$ & $4293 \pm 0.11 \mathrm{~A}$ & $2585 \pm 0.9 \mathrm{~A}$ & $1684 \pm 0.4 \mathrm{~A}$ & $131 \pm 0.5 \mathrm{~A}$ & $87 \pm 0.02 \mathrm{~A}$ \\
\hline Post-treatment & $8748 \pm 0.17 \mathrm{~A}$ & $4270 \pm 0.3 \mathrm{~A}$ & $2496 \pm 0.6 \mathrm{~A}$ & $1786 \pm 0.8 \mathrm{~A}$ & $109 \pm 0.4 \mathrm{~A}$ & $87 \pm 0.9 \mathrm{~A}$ \\
\hline Pre-treatment & $8700 \pm 0.13 \mathrm{~A}$ & $4270 \pm 0.6 \mathrm{~A}$ & $2516 \pm 0.5 \mathrm{~A}$ & $1696 \pm 0.07 \mathrm{~A}$ & $131 \pm 0.05 \mathrm{~A}$ & $87 \pm 0.02 \mathrm{~A}$ \\
\hline $\begin{array}{l}\text { Simultaneous } \\
\text { treatment }\end{array}$ & $8748 \pm 0.17 \mathrm{~A}$ & $4270 \pm 0.3 \mathrm{~A}$ & $2496 \pm 0.6 \mathrm{~A}$ & $1786 \pm 0.8 \mathrm{~A}$ & $109 \pm 0.4 \mathrm{~A}$ & $87 \pm 0.9 \mathrm{~A}$ \\
\hline Drug & $8762.5 \pm 0.25 \mathrm{~A}$ & $4367 \pm 0.11 \mathrm{~A}$ & $2504 \pm 0.11 \mathrm{~A}$ & $1675 \pm 0.04 \mathrm{~A}$ & $131 \pm 0.05 \mathrm{~A}$ & $87 \pm 0.03 \mathrm{~A}$ \\
\hline Plant extract & $8754 \pm 0.13 \mathrm{~A}$ & $4290 \pm 0.11 \mathrm{~A}$ & $2576 \pm 0.15 \mathrm{~A}$ & $1693 \pm 0.9 \mathrm{~A}$ & $109 \pm 0.4 \mathrm{~A}$ & $87 \pm 0.02 \mathrm{~A}$ \\
\hline
\end{tabular}

Differences A, B, C, D, E are significant $(P<0.05)$ to compression rows. 


\section{References}

1. Ernst, E. and Pittler, M.H. (2002). Herbal Medicine. Medical Clinics of North America; 86(1): 149-161

2. Dubreuil, L.I.; Houcke, Y.; Mouton, and Rossignol, J.F. (1996). In vitro evaluation of activities of nitazoxanide and tizoxanide against anaerobes and aerobic organisms. Antimicrob. Agents Chemother. 40:2266-2270.

3. Internet (2005). Metronidazole (Systemic).WWW.Drugs.com

4. Dobell, C. (1990): The discovery of the intestinal protozoa of man. Proc. Roual Soc. Med., 13:1-15.

5. Kusumi, R.K.; Plouffe, J.F.; Wyatt, R.H. and Fass, R.J. (1980). Central nervous system toxicity associated with metronidazole therapy. Ann. Intern. Med., 93:59-60.

6. Donavon, J.M. and Zhiyang, Z. (2004). Integrating In Vitro Kinetic Data from Compounds Exhibiting Induction, Reversible Inhibition and Mechanism-Based Inactivation: In Vitro Study Design, pp. 141-146.

7. Newmark, H.L. (1987). Plant phenolics as inhibitory of mutational and precarcinogenic events. Can.J.Physiol .Pharmacol., 65: 461-661.

8. Morita,K.,Hara ,M. and Kada T. (1978)Studies on natural desmutagens:screening for vegetable and fruit factors active in inactivation of mutagenic pyrolysis products from amino acids,Agric.Biol.Chem.,42:1235-1238.

9. Kuroda, Y. and Hara Y. (1999). Antimutagenicity of tea polyphenoles. Mutation Research, 436:69-97.

10. Ferguson, LR. (1994): Antimutagens as cancer chemopreventive agents in the diet. Mutat Res., 307:395-410.

11. Clarke, C.H. and Shankel, D.M. (1975). Antimutagenesis in microbial systems. Bacteriol Rev 39:33-53.

12. Kuroda, Y. (1990). Animutagenesis studies. In: Basic Life Sciences: Antimutagenesis and Anticarcinogenesis Mechanisms, II. Vol 52 (Kuroda Y, Shenkel DM, Waters MD, eds). New York:Plenum Press, 1-22.

13. Legator, S.; Marvin,T.H. and Marie S. (1975). Detection of mutagenic activity of metronidazole and Niridazole in body fluids of humans and mice. Science .188:11181119.

14. Catalano, P. (2002). White blood cell counts with differential, in George-Gay, B. and Chernecky, C. (eds): Clinical Medical-Surgical Nursing Saunders, pp. 282-290.

15. Rawat, A.K.S.; Mehrotra, S.; Tripothi, S.C. and Shome, U. (1997). Hepatoprotective activity of Boerchaviadiffusa L-roots a popular Indian ethnomedicine . J. Ethno., 56: 61-66.

16. SAS (2001). SAA Guide for personal computer. Release 6.12. SAS Institute Inc., Cary, NC. USA.

17. Kanakis, C.D.; Tarantilis, P.A.; Polissiou, M.G.; Diamantoglou, S. and Tajmir-Riahi, H.A. (2005). DNA Interaction with Naturally Occurring Antioxidant Flavonoids 
Quercetin, Kaempferol, and Delphinidin. Journal of Biomolecular Structure and Dynamics, 22: 6.

18. Alan, L. and Miller, N.D. (1996). Antioxidant Flavonoids: Structure, Functionand Clinical Usage . Alt. Med. Rev., 1:103-111.

19. Pool-Zobel, B. (1998). Mechanisms by which vegetable consumption reduces genetic damage in humans. Cancer Epidemiol Biomarkers Prev, Oct. 7: 891.

20. Bronzetti, G. (1994). The role of antimutagenesis and anticacinogensis. J.Environ. Pathol. ToxicolOncol., 16:259-262.

21. Internet (2001). Bone marrow and White blood cell The goal of cancer treatment with chemotherapy and/or radiation is to interfere with the growth of cancer cells and ultimately destroy them www.Cedars-Sinai program.org. 